Gi respons på artikler gjennom artiklenes kommentarfelt på tidsskriftet.no.

Innleggene publiseres fortløpende på Tidsskriftets nettside og et utvalg

av innleggene publiseres også i papirutgaven i spalten «Brev til redaktøren».

Redaksjonen forbeholder seg retten til å foreta redaksjonelle endringer.

Forfattere av vitenskapelige artikler har tilsvarsrett, jf. Vancouver-gruppens regler.

\section{Re: Omskjæring av gutter}

I Tidsskriftet nr. 21/2015 har M. Bretthauer \& E. Hem på trykk en artikkel om omskjæring av gutter (1). Barneombudet mener det bør være en aldersgrense på 15 eller 16 år på omskjæring. Da kan gutten selv samtykke til gjennomføringen av et rituelt inngrep uten signifikant medisinsk nytteverdi på sin kropp.

Omskjæring uten medisinsk indikasjon hos et barn uten samtykkekompetanse bryter med grunnleggende medisinsk-etiske prinsipper. Inngrepet er irreversibelt, smertefullt og kan medføre alvorlige komplikasjoner. Dette synet støttes av alle de nordiske barneombudene og nordiske barnemedisinske eksperter, deriblant Den norske barnelegeforeningen, Barnekirurgisk forening og Rådet for legeetikk. Også Legeforeningen støtter dette synet.

Artikkelen til Bretthauer \& Hem lener seg på studier om hivsmitte og forebygging av HPV, studier som har liten relevans for små barn i Norge. Dette er argumenter vi har imøtegått ved flere anledninger, blant annet i den kronikken det vises til i artikkelen.

Vi kan ikke se at artikkelen bringer nye vektige argumenter inn i denne debatten. Derimot har vi siden rituell omskjæring av gutter ble debattert sist fått en ny grunnlovsbestemmelse som styrker barnets rett til å bli hørt og barnets rett til personlig integritet. Dette bør heve terskelen ytterligere for å utsette små gutter uten samtykkekompetanse for rituelle kirurgiske inngrep.

\section{Anne Lindboe}

anne@barneombudet.no

Anne Lindboe (f. 1971) er barneombud.

Ingen oppgitte interessekonflikter.

\section{Litteratur}

1. Bretthauer M, Hem E. Omskjæring av gutter. Tidsskr Nor Legeforen 2015; 135 $1926-7$.

\section{Bretthauer \& E. Hem svarer:}

Anne Lindboe fastholder sin inndeling i rituell og medisinsk omskjæring. Vi ønsket med vårt innlegg å problematisere denne inndelingen ettersom helsegevinstene er de samme. Lindboe hevder at omskjæring er «uten signifikant medisinsk nytteverdi». Tidligere har hun påstått at slike effekter ikke finnes (1). Vi tolker den nye formuleringen som et skritt i riktig retning. Debatten handler om hvorvidt helseeffektene av omskjæring er klinisk signifikante sammenholdt med inngrepets art og komplikasjoner.

De smittepreventive virkningene av omskjæring gjelder selvsagt ikke når barnet er lite. Derfor gir Lindboes argument om at småbarn ikke har nytte av omskjæring liten mening. Lindboe fremfører også at flere organisasjoner er enig med henne. Vi kunne anført det samme, men finner det lite hensiktsmessig. Medisinsk evidens defineres ikke etter flertallsprinsippet lenger.

\section{Michael Bretthauer \\ michael.bretthauer@medisin.uio.no \\ Erlend Hem}

Michael Bretthauer (f. 1969) er dr.med., professor ved Avdeling for helseledelse og helseøkonomi, Universitetet i Oslo og overlege ved Seksjon for fordøyelsessykdommer, Avdeling for transplantasjonsmedisin, Oslo universitetssykehus.

Ingen oppgitte interessekonflikter.
Erlend Hem (f. 1970) er dr.med., fagsjef ved Klinikk psykisk helse og avhengighet, Oslo universitetssykehus og redaktør for Tidsskriftets språkspalte.

Ingen interessekonflikter.

\section{Litteratur}

1. Lindboe A. Vern også guttebarn mot omskjæring. NRK Ytring 18.3.2013. www.nrk.no/ytring/vern-ogsa-guttebarn-mot-omskjaering-1.10953417 (19.11.2015).

\section{Re: Praksiskonsulentordningen ved et veiskille}

Torkel Steen kommenterer i Tidsskrift nr. 20/2015 Odd Kvammes innlegg om praksiskonsulentordningen (1). Steen stiller kritiske spørsmål om praksiskonsulentordningens nytteverdi generelt og kommenterer praksiskonsulentordningen på Oslo universitetssykehus spesielt. Blant annet savner han nye versjoner av informasjonsbladet «Fastlegenytt».

Oslo universitetssykehus har dessverre ikke hatt praksiskonsulentordning de siste to år. Vi er glade for at vi fra 1. november 2015 har fått en samhandlingsoverlege (tidligere fastlege) i $100 \%$-stilling sammen med en ny praksiskonsulent i $20 \%$-stilling. I den tiden Oslo universitetssykehus hadde praksiskonsulentordning (fra sammenslåingen av Oslo-sykehusene i 2009 til september 2013), bidro praksiskonsulentene på vesentlige områder til utvikling av samhandling i sykehuset.

Eksempelvis deltok de i arbeid med utforming av en overordnet rutine for epikrise i Oslo universitetssykehus. Sammen med andre bidro de til en større oppgradering av «Veiviser for helsepersonell». Veiviseren er et oppslagsverk som hjelper helsearbeidere i og utenfor sykehus til å navigere i helsetjenesten i Oslo-området.

Praksiskoordinator laget et «henvisningskart» til bruk for fastleger og andre henvisere da ny henvisningsstruktur ble etablert i Oslo universitetssykehus i 2012. Henvisningskartet ble også til nytte for medarbeidere internt i Oslo universitetssykehus. Praksiskonsulentene samlet post- og e-postadresser til alle fastleger i Oslo. De etablerte en passordbeskyttet liste med direktetelefoner til alle fastleger i Oslo, til bruk for samarbeidende helsepersonell. Praksiskoordinator var redaktør for infobladet «Fastlegenytt».

Oslo universitetssykehus har vel 20000 ansatte. Praksiskonsulentene hadde til sammen 1,3 stillingshjemmel fordelt på 5 personer. Ikke så rart da, kanskje, at Torkel Steen ikke har møtt dem personlig. Men kanskje har han hatt nytte av praksiskonsulentordningens innsats uten å være klar over det? Praksiskonsulent og samhandlingsoverlege er allerede i arbeid med pakkeforløp, Fastlegenytt samt andre saker i grenseflaten mellom sykehus og kommunehelsetjeneste. Vi ser mange områder der kompetansen medarbeiderne fra primærhelsetjenesten har, er viktig for å utvikle pasientens helsetjeneste videre.

\section{Tove Strand}

tove.strand@ous-hf.no

Tove Strand (f. 1946) er viseadministrerende direktør ved Oslo universitetssykehus.

Ingen oppgitte interessekonflikter.

\section{Litteratur}

1. Kvamme 0. Praksiskonsulentordningen ved et veiskille. Tidsskr Nor Legeforen 2015; 135: 1440 